ernment/psa) contains all the $\mathrm{Na}$ tional Office publications and administrative forms, as well as $P i$ Sigma Alpha Newsletter. Chapters with home pages should give their addresses to the National Office so that they can be listed there.

Chapter Activity Grants Awarded. $\Pi \Sigma A$ chapters in the following schools received Chapter Activity Grants for 1996-97:

\section{Additional Dissertation Listing}

The following dissertations should be included in the compilation of completed doctoral dissertations in political science, 1995, listed in the December 1996 issue of PS.

\section{American Government}

Clayton, Dewey: B.A., Morehouse College, 1981; M.P.A., North Carolina Central University, 1987; Ph.D., University of Missouri-Columbia, 1995. The Politics of Redistricting: A North Carolina Case Study. University of MissouriColumbia.

\section{Comparative Politics}

An, Soon Cheol: B.A., Dankook University (Korea), 1985; M.A., Oklahoma
State University, 1987; Ph.D., University of Missouri-Columbia, 1995. Electoral Choice in Korea: A Spatial Analysis of Ideology and Sophisticated Voting. University of Missouri-Columbia.

Birch, Timothy J: B.A., University of Manchester, 1985, M.A., University of Missouri-Columbia, 1989; Ph.D., Ibid., 1995. After the Threat: NATO and European Defense in the Post-Cold War Era. University of Missouri-Columbia.

DaSoller, Claudio: B.A., The Polytechnic of Central London (London), 1986; M.A., University of Missouri-Columbia, 1989; Ph.D., Ibid., 1995. The Nonprofit Sector in the Fields of International Relief, Health and Nutrition, and Food Aid: Private Voluntary Organizations and the State. University of MissouriColumbia.

Jawadi, Mostafa: Mohamed V. University (Morocco), 1976, License in Law; M.P.A., California State University, Chico, 1988; Ph.D., University of Missouri-Columbia, 1995. Regional Integration in the Maghreb. University of Missouri-Columbia.

Lee, Wonkyoo: B.A., Seoul National University (Korea), 1977; M.P.A., Ibid., 1981; Ph.D., University of Missouri-Columbia, 1995. Political Culture in the Republic of Korea and Its Effects on Parties and Elections. University of Missouri-Columbia.

Veney, Cassandra R.: B.A., Syracuse University, 1982; M.A., Howard Univer- sity, 1988; Ph.D., University of MissouriColumbia, 1995. The Politics of Refugee Relief Programs in Kenya. University of Missouri-Columbia.

\section{International Relations}

Chung, Sam-man: B.S. Republic of Korean Naval Academy, 1981; M.A., National Defense College (Korea), 1990; Ph.D., University of Missouri-Columbia, 1996. Causes and Effects of U.S. Military Expenditures (Time Series Models and Applications). University of MissouriColumbia.

Park, Chang-Kwoun: B.A., Korea Naval Academy, 1981; M.A., National Defense College (Korea), 1989; Ph.D. University of Missouri-Columbia, 1996. Political Consequences of Shows-ofForce. University of Missouri-Columbia.

Song, Seung-jong: B.A., Korea Military Academy, 1981; M.A., National Defense College (Korea), 1989; Ph.D., University of MBFR and CFE. University of Missouri-Columbia.

\section{Methodology}

MacDonald, John T.: B.S., University of Minnesota-Minneapolis, 1980; M.P.A., ibid, 1985; Ph.D., University of MissouriColumbia, 1995. Information Theory, Cellular Autonata, and Political Science. University of Missouri-Columbia. 